\title{
PENGOLAHAN LIMBAH AYAM PETELUR SEBAGAI PUPUK ORGANIK
}

\section{The Processing of Laying Hens Manure as Organic Fertilizer}

\author{
Abdul Halim ${ }^{1}$ \\ ${ }^{1}$ Program Studi Teknik Kimia, Fakultas Sains dan Teknologi, Institut Sains dan Teknologi Al-Kamal \\ Jakarta \\ Email : halim.abe@gmail.com
}

\begin{abstract}
ABSTRAK
Penelitian ini bertujuan untuk mengevaluasi kualitas pupuk organik yang dihasilkan dari proporsi kotoran ayam petelur dengan sekam padi. Penelitian ini menggunakan Rancangan Acak Kelompok (RAK) dengan 3 level perlakuan rasio kotoran ayam petelur dan sekam padi yaitu P1 (1:1), P2 (2:1), dan P3 (1:2). Penelitian diulang sebanyak 4 kali. Parameter yang diamati dalam penelitian ini adalah nitrogen $(\mathrm{N})$, fosfor $(\mathrm{P})$, kalium $(\mathrm{K})$, karbon $(\mathrm{C})$ organik, rasio $\mathrm{C} / \mathrm{N}$, dan pH. Hasil penelitian menunjukkan rasio kotoran ayam petelur dan sekam padi berpengaruh nyata terhadap kandungan $\mathrm{N}, \mathrm{P}, \mathrm{K}, \mathrm{C}$ organik, dan rasio $\mathrm{C} / \mathrm{N}$. Pupuk organik ayam petelur dengan imbangan sekam padi 2:1 paling tinggi mengandung $\mathrm{N}(5,6 \%), \mathrm{P}(2,5 \%), \mathrm{C}(35,6 \%), \mathrm{K}(2,1 \%)$, dengan kelembapan $32,4 \%$.
\end{abstract}

Kata kunci: Ayam Petelur, Kotoran Ayam, Sekam Padi, Pupuk Organik

\section{ABSTRACT}

This study aims were to evaluate the quality of organic fertilizers produced from the proportion of laying hen manure with rice husks. This study was use a randomized block design (RBD) with 2 levels treatment of layer chicken manure and rice husk ratio, i.e P1 (1: 1), P2 (2:1), and P3 (1:2). The research was repeated 4 times. The parameters observed in this study were nitrogen $(N)$, phosphorus $(P)$, potassium (K), organic carbon (C), $C / N$ ratio, and $\mathrm{pH}$. The results showed that the ratio of layer chicken manure and rice husk significantly affected the organic $N, P, K, C$ content and $C / N$ ratio. Organic fertilizer for laying hens with a balance of rice husk 2:1 contains the highest $N$ (5.6\%), $P(2.5 \%), C$ (35.6\%), K (2.1\%), humidity $32.4 \%$

Keywords: Laying Hen, Manure, Rice Husks, Organic Fertilizer

\section{PENDAHULUAN}

Pertanian intensif merupakan salah satu kegiatan utama penyebab tingginya input pupuk dan pestisida. Penggunaan tanah secara intensif selama bertahun-tahun, bersama dengan teknologi produksi yang tidak tepat seperti pembersihan tanah secara terus menerus, penggunaan pestisida dan pupuk secara luas, dalam banyak kasus telah menciptakan masalah besar dalam hal polusi dan degradasi tanah (Jason \& Walton, 2019). Oleh karena itu, minimalisasi dampak lingkungan tanpa mengurangi hasil pertanian adalah suatu isu krusial untuk mencapai produksi pertanian yang berkelanjutan.

Keberlanjutan produksi dan produktivitas agroekosistem jangka panjang adalah proses yang menjaga bahan organik di dalam tanah. Penggunaan pupuk organik di tanah merupakan strategi pengelolaan yang akan membantu dalam mengatasi hilangnya bahan organik secara progresif baik dalam jangka pendek maupun jangka panjang. Penambahan pupuk organik meningkatkan sifat fisika-kimia tanah, biokimia dan mikrobiologi tanah sehingga secara positif mempengaruhi parameter kualitas tanah dan produktivitas tanaman (Singh, 2012). 
Pupuk organik dapat terjadi secara alamiah atau dibuat dengan bahan organik. Pupuk organik yang terjadi secara alami diantaranya pupuk kandang dan slury, sedangkan pupuk organik yang diproses diantaranya kompos, tepung darah dan asam humat (Singh, 2012). Meskipun kepadatan nutrisi dalam bahan organik relatif sederhana namun memiliki beberapa kelebihan dibandingkan dengan pupuk anorganik. Sebagian besar dari nitrogen yang memasok pupuk organik mengandung nitrogen yang tidak larut dan bertindak sebagai pelepasan lambat pupuk. Sesuai sifatnya, pupuk organik meningkatkan penyimpanan hara fisik dan biologis mekanisme di tanah, mengurangi risiko pemupukan berlebihan.

Nutrisi penyubur organik kandungan, kelarutan, dan laju pelepasan unsur hara biasanya jauh lebih rendah daripada mineral (anorganik) pupuk. Pupuk organik juga kembali mempertegas peran humus dan lainnya pada komponen organik tanah, yang diyakini memainkan beberapa peran penting yaitu (1) Mobilisasi unsur hara tanah yang ada, sehingga pertumbuhan yang baik dicapai dengan kepadatan hara yang lebih rendah; (2) Melepaskan nutrisi pada kecepatan yang lebih lambat dan lebih konsisten sehingga membantu menghindari boom-and-bust pola; (3) Membantu mempertahankan kelembaban tanah, mengurangi stres akibat stres kelembaban sementara; (4) memperbaiki struktur tanah; (5) membantu mencegah erosi lapisan tanah atas (Kumar \& Gopal, 2015). Salah satu bahan organik melimpah yang dapat digunakan sebagai bahan pupuk adalah kotoran ternak (Utami, et al., 2020).

Pengolahan kotoran ternak menjadi pupuk dimaksudkan untuk meminimalkan masalah yang timbul dari peternakan serta meningkatkan nilai tambah usaha peternakan. Selama ini kotoran yang umum digunakan sebagai bahan baku pupuk organik adalah kotorsan sapi dan kambing, sedangkan kotoran ayam masih terbatas digunakan sebagai bahan baku pembuatan pupuk organik. Padahal kotoran ayam negeri baik petelur maupun ayam potong, memiliki komposisi hara yang tinggi akibat pemberian nutrisi untuk meningkatkan bobot daging atau telurnya. Tentunya beberapa nutrisi tidak tercerna dan dibuang melalui fesesnya.

Melalui penelitian ini, diharapkan dapat memberikan informasi mengenai keunggulan unsur hara yang dapat dihasilkan dari pupuk organik berbahan kotoran ayam yang dibuat dengan teknologi industri rumah tangga.

\section{METODE}

Penelitian dilaksanakan pada Bulan Januari - Maret 2020 yang berlokasi di Laboratorium Proses Kimia Institut Sains dan Teknologi Al Kamal, Jakarta Barat. Bahan yang digunakan dalam pembuatan pupuk organik adalah kotoran ayam petelur, sekam padi dan tanah liat yang didapatkan dari Pertanian dan Peternakan ayam petelur Sayaka Bumi Farm, Parung Bogor. Parameter uji adalah komposisi N, P, K, C organik, C/N rasio dan kelembapan. Data dianalisis dengan ANOVA dan uj ilanjut Duncan.

Prosedur pembuatan pupuk organik adalah sebagai berikut :

1. Kotoran ayam petelur dikeringkan dibawah sinar matahari selama 6-7 jam.

2. Kotoran ayam kering dicampurkan dengan sekam padi yang sudah dibakar sesuai perlakuan rasio kotoran ayam : sekam padi yaitu P1 (1:1), P2 (2:1), dan P3 (1:2).

3. Bakar campuran kotoran ayam dan sekam padi selama 30 menit.

4. Tambahkan campuran tanah liat: air (1:4) kedalam campuran kotoran ayam dan sekam padi yang sudah dibakar dengan rasio 1:1. Diamkan selama 24 jam.

5. Keringkan campuran tersebut dibawah sinar matahari selama 6-7 jam.

6. Pupuk organik siap digunakan. 


\section{HASIL DAN PEMBAHASAN}

Pupuk organik dibuat dari kotoran ayam dan sekam padi. Kotoran ayam sebelumnya dikeringkan dan sekam padi yang akan digunakan, dibakar hingga hitam. Campuran bahan baku pupuk organik kemudian dibakar kembali. Selanjutnya ditambahkan tanah liat encer sebagai perekat, didiamkan selama 24 jam dan dijemur selama 6 - 7 jam. Pupuk organik yang dihasilkan tersebut dapat langsung digunakan. Pengeringan dan pembakaran berulang pada bahan baku pupuk organik dilakukan untuk menurunkan suhu kotoran ayam agar tidak merusak tanah dan tanaman (Sumarno, 2017). Analisis dilakukan pada setiap perlakuan imbangan pupuk organik, berdasarkan hasil penelitian, komposisi pupuk organik dari campuran kotoran ayam petelur dan sekam padi disajikan pada Tabel 1.

Tabel 1. Hasil analisis komposisi pupuk organik kotoran ayam petelur dan sekam padi

\begin{tabular}{lccccc}
\hline \multirow{2}{*}{ Parameter Uji } & \multicolumn{2}{c}{ Perlakuan Kotoran Ayam: Sekam Padi } & \multicolumn{2}{c}{$\begin{array}{c}\text { Parameter } \\
\text { SNI 19-7030-2004 }\end{array}$} \\
\cline { 2 - 6 } & P1 (1:1) & P2 (2:1) & P3 (1:2) & Minimum & Maksimum \\
\hline N (\%) & $3,4^{\mathrm{b}}$ & $5,6^{\mathrm{c}}$ & $1,3^{\mathrm{a}}$ & 0,4 & - \\
$\mathrm{P}(\%)$ & $1,1^{\mathrm{a}}$ & $2,5^{\mathrm{b}}$ & $3,7^{\mathrm{c}}$ & 0,1 & - \\
K $(2,1)$ & $1,6^{\mathrm{a}}$ & $2,1^{\mathrm{b}}$ & $3,8^{\mathrm{c}}$ & 0,2 & - \\
C organik (\%) & $25,6^{\mathrm{a}}$ & $35,6^{\mathrm{b}}$ & $58,1^{\mathrm{c}}$ & 9,8 & 32 \\
C/N rasio & $7,5^{\mathrm{a}}$ & $6,4^{\mathrm{a}}$ & $44,7^{\mathrm{b}}$ & 10 & 20 \\
Kelembapan (\%) & $53,7^{\mathrm{c}}$ & $32,4^{\mathrm{ab}}$ & $28,5^{\mathrm{a}}$ & 0 & 50 \\
pH & $5,7^{\mathrm{a}}$ & $6,2^{\mathrm{b}}$ & $7,6^{\mathrm{c}}$ & 4 & 7,49 \\
\hline
\end{tabular}

Sumber: Hasil penelitian (2020)

Tabel 1 memperlihatkan semua perlakuan menunjukkan hasil berbeda secara nyata pada komposisi pupuk yang dihasilkan berdasarkan perlakuan dalam penelitian yang ditunjukkan dengan notasi yang berbeda - beda yaitu a, b, ab, dan c. Berdasarkan SNI (2018), perlakuan yang paling mendekati baik adalah perlakuan P2 dengan nilai kelembapan 32,4\% dan kadar nitrogen paling tinggi yaitu 5,6\%. Kadar nitrogen dipengaruhi oleh pakan yang dikonsumsikan pada ayam petelur, semakin tinggi kandungan protein pakan, maka akan semakin tinggi kandungan $\mathrm{N}$ dalam kotorannya. Salah satu pakan yang menyebabkan kandungan $\mathrm{N}$ tinggi dalam kotoran ayam adalah jagung, dedak jagung atau daun jagung. Sekam padi juga turut mempengaruhi kandungan $\mathrm{N}$ dalam pupuk yang dihasilkan. Pembakaran pada sekam padi dapat menguraikan serat kasar seperti selulosa, hemiselulosa dan lignin menjadi komponen yang lebih sederhana (Muslim, 2018). Komponen C hasil pembakaran dari sekam padi dapat dimanfaatkan mikroorganisme dalam proses fermentasi alami singkat.

Tabel 1 memperlihatkan bahwa pupuk organik yang dihasilkan memiliki kadar NPK sesuai persyaratan (SNI, 2018). Kadar C organik perlakuan P1 sesuai SNI, sedanglan perlakuan P2 dan P3 melebihi ambang standar SNI. Hal tersebut disebabkan oleh pupuk yang difermentasikan secara singkat sehingga pupuk masih dalam keadaan mentah atau belum cukup mengalami proses pengomposan. Proses pengomposan menyebabkan kadar bahan organik dalam bahan kompos yang semula tinggi menjadi rendah (Li et al., 2020). Proses pengomposan, mikroorganisme memanfaatkan $\mathrm{C}$ organik sebagai sumber karbon untuk menghasilkan energi. Mikroorganisme akan mati dan unsur hara penyusun mikroorganisme dilepaskan, sehingga kadar $\mathrm{C}$ organik turun, dilepaskan menjadi $\mathrm{CO}_{2}$. Akibatnya rasio $\mathrm{C} / \mathrm{N}$ juga menjadi lebih rendah. Penambahan sekam padi pada perlakuan $\mathrm{P} 3$ menjadi 
2 kali lipat, turut menambah kandungan C organik dalam pupuk yang dihasilkan. Sekam padi adalah sumber C-organik.

Pembakaran pada sekam padi dimaksudkan untuk mendekomposisi atom $\mathrm{C}$ dalam bentuk kompleks seperti selulosa menjadi lebih sederhana untuk didekomposisi mikroorganisme. Pembakaran pada sekam padi juga dimaksudkan untuk meningkatkan mineral dalam campuran pupuk yang dihasilkan. Sekam padi adalah penyumbang komponen Kalium dalam pupuk organik. Berdasarkan Tabel 1 dapat dilihat bahwa penambahan jumlah kalium dan phosphor pada pupuk lebih besar pada perlakuan penambahan sekam padi dengan perbandingan 2:1 (P2) dari kontrol (tanpa penambahan sekam padi) P1.

Kadar nitrogen dalam pupuk yang dihasilkan melampaui jumlah nitrogen yang disyaratkan dalam SNI. Kotoran ayam yang digunakan perlu dikeringkan terlebih dahulu, hal tersebut dilakukan untuk menghindari terbentuknya gas amoniak berlebih yang dapat menyebabkan bau busuk. Perombakan protein dalam kotoran ayam menjadi asam amino yang selanjutnya menjadi gas amoniak menyebabkan aroma busuk. Gas amoniak akan bereaksi dengan air dan berubah menjadi ammonium yang mudah tersedia untuk mikroba dan tanaman melalui proses amonifikasi. Apabila kondisi baik, maka akan terjadi proses nitrifikasi. Jumlah $\mathrm{N}$ yang teridentifikasi dalam pupuk yang dihasilkan adalah berasal dari asam amino dalam kotoran ayam. Tingginya kandungan $\mathrm{N}$ pada perlakuan dalam penelitian menunjukkan bahwa kotoran ayam yang digunakan masih segar, belum terdekomposisi menjadi gas amoniak (Li et al., 2020).

\section{KESIMPULAN}

Rasio kotoran ayam petelur dan sekam padi berpengaruh nyata terhadap kandungan N, P, K, C organik, dan rasio $\mathrm{C} / \mathrm{N}$. Pupuk organik ayam petelur dengan imbangan sekam padi 2:1 paling tinggi mengandung $\mathrm{N}(5,6 \%)$, P (2,5\%), C (35,6\%), K (2,1\%), dengan kelembapan 32,4\%.

\section{DAFTAR PUSTAKA}

SNI. (2018). Syarat Mutu Pupuk An-Organik Dan Organik. Badan Standardisasi Nasional.

Jason, G \& Walton J. (2019). Improving the value and sustainability of laying hen manure: $A$ british free range egg producers association sustainability scheme report. Aberystwyth: ADAS.

Kumar, B. L., \& Gopal, D.V.R.S. (2015). Effective role of indigenous microorganisms for sustainable environment. Biotech, 5(6), 867-876.

Li, X., Li, B., \& Tong, Q. (2020). The effect of drying temperature on nitrogen loss and pathogen removal in laying hen manure. Sustainability, 12(1), 1-11.

Muslim, I. B. (2018). Pemanfaatan limbah pasar dan feses ayam untuk meningkatkan produktivitas tanaman jagung (Zea mays). Warta Pengabdian, 12(1), 212-220.

Singh, R. P. (2012). Organic fertilizers: Types, Production and Environmental Impact. New York: Nova Science Publisher Inc.

Sumarno. (2017). Pemanfaatan limbah ayam broiler sebagai pupuk organik pada usaha pembibitan tanaman. PRIMA, 1(1), 1-4.

Utami, M. M. D., Sutirtoadi, A., Jawawi, A. J. A., \& Dewi, A. C. (2020). Evaluation of the quality of organic fertilizer on different ratio of cow manure and laying hens manure. IOP Conference Series: Earth and Environmental Science, 411(1), 1-5. 